\title{
Ancaman Non-Militer Terhadap Keamanan Nasional di Papua
}

\author{
Jerry Indrawan \\ Program Studi Ilmu Hubungan Internasional, Universitas Paramadina \\ Email: jerry_indrawan18@yahoo.co.id
}

\begin{abstract}
Abstrak
Pertahanan negara merupakan salah satu elemen pokok suatu negara karena menyangkut kepentingan perlindungan warga negara, wilayah, dan sistem politiknya dari ancaman negara lain. Situasi di Papua tidak dapat dikategorikan sebagai konflik bersenjata, tetapi lebih bisa dikategorikan sebagai kekacauan, ketegangan, atau gangguan dalam negeri. Ancaman non-militer pada hakikatnya adalah ancaman yang menggunakan faktor-faktor nirmiliter yang dinilai mempunyai kemampuan yang membahayakan kedaulatan negara, keutuhan wilayah negara, dan keselamatan segenap bangsa. Keinginan masyarakat Papua untuk merdeka lebih disebabkan karena mereka tidak mengalami kesetaraan dalam hal kesejahteraan dengan propinsi-propinsi lain di Indonesia. Jika tidak ada penanganan yang serius, kondisi ini akan berkembang menjadi kondisi permanen yang tentunya akan menjadi ancaman besar terhadap keamanan nasional.
\end{abstract}

Kata Kunci: ancaman non-militer, pertahanan negara, keamanan nasional, dan papua

\section{Abstract}

National defense is one of the basic elements of a country because it involves the need to protect citizens, regions and political systems from the threat of another country. The situation in Papua can not be categorized as an armed conflict, but rather categorized as chaos, tension, or domestic disturbance. Non-military threats in essence are threats using non-military factors to endanger state sovereignty, territorial integrity, and safety of the entire nation. Papua's desire for independence is mainly because they do not have equality, in terms of the welfare, compared to other provinces in Indonesia. If there is no serious treatment, this condition will develop into a permanent condition, which would certainly be a major threat to national security

Keywords: non-military threats, national defense, national security, and papua

\section{Pendahuluan}

Selain ancaman militer yang
menggunakan kekuatan bersenjata
dan
terorganisasi, dewasa ini, muncul juga
ancaman non-militer. Ancaman non-militer
pada hakikatnya adalah ancaman yang
menggunakan faktor-faktor non-militer yang
dinilai mempunyai kemampuan yang
membahayakan kedaulatan negara, keutuhan
wilayah negara, dan keselamatan segenap
bangsa. ${ }^{1}$ Ancaman non-militer dapat
berdimensi ideologi, politik, ekonomi, sosial budaya, teknologi dan informasi, serta keselamatan umum. $^{2}$

\footnotetext{
${ }^{1}$ Jerry Indrawan. 2015. Studi Strategis dan Keamanan. Jakarta: Nadi Pustaka. Hal. 69.

${ }^{2}$ Ibid. Hal. 69.
}

Ancaman non-militer sangat berdimensi sosial budaya karena sifatnya yang internal, atau muncul dari dalam negara. Ancaman jenis ini berdimensi sosial budaya karena didorong oleh isu-isu kemiskinan, kebodohan, keterbelakangan, dan ketidakadilan. Isu-isu ini sangat terkait dengan masalah-masalah sosial budaya. $^{3}$ Isu-isu tersebut kemudian berkembang menjadi titik pangkal timbulnya permasalahan, seperti separatisme, terorisme, kekerasan, dan bencana akibat perbuatan manusia. Permasalahan ini lama-lama menjadi "kuman penyakit" yang mengancam persatuan dan kesatuan bangsa,

\footnotetext{
${ }^{3}$ Ibid. Hal. 65 .
} 
nasionalisme, patriotisme, dan keamanan nasional.

Membahas masalah Papua seperti tidak ada habis-habisnya di republik ini. Penulis melihat bahwa pemekaran Papua yang eksesif, bukan sebagai solusi, melainkan menunjukkan ketidaksungguhan pemerintah menuntaskan masalah Papua. Menurut penulis, selain menimbulkan kebingungan, pemekaran Papua tergolong tergesa-gesa, serta secara tidak langsung mencerminkan ketidakmampuan Jakarta berdialog dengan masyarakat Papua dalam menyelesaikan masalah-masalah yang seharusnya dimasukkan dalam bingkai NKRI. Sayangnya, menurut penulis pemerintah masih memperlakukan Papua semata-mata dari sudut ancaman separatisme. Cara pandang yang tak ubahnya dengan cara pandang di era Orde Baru dulu.

Problematika Papua dan daerah-daerah konflik lainnya semestinya dilihat dari sudut pandang yang lebih komprehensif, seperti masalah ketidakadilan sosial, absennya penghargaan terhadap keunikan sejarah, budaya, ras, lokalitas, dan lain sebagainya. Dalam konteks ini, pemekaran wilayah bukan sesuatu yang haram, asalkan ada rasionalitasnya, melalui proses dialog yang jujur, dan tak melanggar UU yang berlaku.

Ditinjau dari segi ras, budaya, dan sejarah, masalah Papua memang memiliki nuansa "berbeda". Papua tak hanya berbeda dari sudut budaya dan ras dengan Indonesia, tapi juga pengalaman historisnya di bawah penjajahan Belanda. ${ }^{4}$ Bung Hatta pernah

\footnotetext{
${ }^{4}$ George Junus Aditjondro. 2000. Cahaya Bintang Kejora: Papua Barat dalam Kajian Sejarah, Budaya,
}

mengakui keunikan Papua, saat berdebat menentukan status Papua pada sidang persiapan kemerdekaan Indonesia, Bung Hatta bahkan cenderung berpendapat agar rakyat Papua menentukan sendiri nasibnya. ${ }^{5}$ Sementara itu, Bung Karno lebih menekankan pada aspek strategis-politis. Jika Papua lepas ke negara lain bisa berdampak kepada Indonesia. Lagipula, Papua juga berada di bawah kolonial Belanda dan daerah itu (Boven-Digul) pernah menjadi tempat pembuangan tokoh-tokoh pergerakan Indonesia. $^{6}$ Menurut Soekarno pula, dalam kitab Negarakertagama disebutkan bahwa Papua masuk wilayah Majapahit. Pada akhirnya, melalui voting, mayoritas pendiri negara memilih Papua untuk bergabung dengan Republik Indonesia. ${ }^{7}$

Keunikan sejarah Papua lainnya adalah saat proses integrasi. Sampai 1963, wilayah itu menjadi sengketa antara Indonesia dan Belanda. Setelah melalui pemerintahan sementara $\mathrm{PBB}$, barulah Indonesia secara de facto berkuasa atas Papua tahun 1963. Tahun 1969 integrasi Papua diperkuat lewat Penentuan Pendapat Rakyat (Pepera) yang secara aklamasi menyatakan tergabung dengan NKRI. Aklamasi saat Pepera inilah yang seharusnya menyadarkan kita bahwa masyarakat Papua memilih dengan hati mereka untuk bergabung dengan NKRI.

ekonomi, dan Hak Asasi Manusia. Jakarta: Elsam.

Hal. 7

${ }^{5}$ Ibid. Hal. 7.

${ }^{6}$ Ibid. Hal. 7.

7 BIK. Pigay dan Decki Natalis. 2000. Evolusi Nasionalisme dan Sejarah Konflik di Papua. Jakarta: Pustaka Sinar Harapan. Hal. 191. 
Ketika masih menyelesaikan studi di Universitas Pertahanan, Prof. Susanto Zuhdi, Guru Besar Ilmu Sejarah Universitas Indonesia, yang kebetulan mengajar penulis di sana, pernah berkata: "[..s]eperti layaknya perjalanan sebuah kereta api, penumpangnya tidak harus berangkat dari stasiun awal. Ada yang baru naik pada stasiun-stasiun berikutnya, dan akhirnya semua sampai bersama-sama ke tujuan”. Orang Papua memang tidak dari awal kemerdekaan bergabung dengan NKRI, tetapi seiring berjalannya waktu kesamaan tujuan dan visi bangsa mereka ternyata sama dengan NKRI, sehingga akhirnya mereka pun secara aklamasi menyatakan kesediaannya bergabung dengan kita.

Karena itu, patut disesalkan pendekatan monolitik pemerintah terhadap Papua selama ini. Dengan latar belakang sejarah integrasi yang kontroversial, seharusnya yang dilakukan Jakarta adalah mengambil hati masyarakat Papua. Pendekatan keamanan seharusnya tidak lagi digunakan, sekalipun kerangka penyelesaian masalah di Papua tetap harus dilihat dari sudut pandang ancaman terhadap keamanan nasional. Dengan bergesernya definisi keamanan dan ancaman militer, tulisan ini akan membahas bagaimana menyelesaikan masalah Papua dengan terlebih dulu melihat masalah ini dari perspektif keamanan nasional dan ancaman non-militer.

\section{Definisi Ancaman Non-Militer dan}

\section{Keamanan Nasional}

Seperti yang sudah disebutkan, definisi ancaman militer dan keamanan sudah jauh mengalami perkembangan dewasa ini, terutama pasca runtuhnya Uni Soviet. Perubahan lingkungan keamanan pasca perang dingin memiliki enam dimensi. ${ }^{8}$

Pertama, pergeseran sumber ancaman dari lingkungan eksternal menjadi lingkungan domestik. Kedua, perubahan sifat ancaman dari militer menjadi non-militer. Ketiga, perubahan respon dari militer menjadi non-militer. Keempat, perubahan tanggung jawab keamanan dari negara menuju kolektif. Kelima, perubahan nilai inti keamanan dari negara menjadi individual, dan dari nasional menjadi keamanan global. Dan keenam, kebijakan pembangunan instrumen militer menuju pada kebijakan keamanan yang memfokuskan pada pembangunan manusia yang berkelanjutan.

Ancaman terhadap keamanan nasional dapat dipahami atau didefinisikan sebagai suatu tindakan atau serangkaian peristiwa yang dapat memberikan ancaman dalam dua dimensi sekaligus, yaitu secara langsung atau tidak langsung membahayakan kehidupan masyarakat; dan untuk membatasi pilihanpilihan kebijakan pemerintah. Atas dasar itu, analisa ancaman dapat dilakukan melalui dua metode, yaitu (1) berdasarkan ancaman (threat based assessment), atau analisa mengenai kalkulasi ancaman yang dihadapi; dan (2) berdasarkan kapabilitas (capability based assessment), atau analisa mengenai kalkukasi kemampuan untuk bisa melakukan suatu tindakan militer. ${ }^{9}$

Penulis berpendapat bahwa untuk melihat faktor-faktor yang menjadi ancaman,

\footnotetext{
${ }^{8}$ Indrawan. Op cit. Hal. 7.

${ }^{9}$ Ibid. Hal. 11.
} 
resiko, dan bencana terhadap Papua, lebih baik dipandang dari sudut pandang keamanan nasional. Penulis tidak mengatakan bahwa gangguan keamanan yang terjadi di Papua, yang menggunakan kekuatan senjata, bukan merupakan ancaman bagi keamanan nasional. Akan tetapi, penulis akan menitikberatkan kepada ancaman non-militer, di mana ditakutkan akan menjadi permanen, serta derajat ancamannya terhadap keamanan nasional akan meningkat di masa depan. Penulis tidak merasa kondisi konflik di Papua akan mengarah pada terjadinya konflik bersenjata (armed conflict), akan tetapi ancaman terkait konteks human security akan meluas, sehingga bisa memperpanjang terjadinya konflik (prolong)

Inilah perspektif baru keamanan nasional, yakni dalam arti besar mencakup negara bangsa (yang bukan merupakan entitas tunggal) dan masyarakat (publik dan individu). Salah satunya adalah human security atau biasa juga dikenal dengan terminologi keamanan insani. Seperti yang dikatakan Vaclav Havel: "kedaulatan masyarakat, wilayah, bangsa, negara, hanya bermakna jika berasal dari kedaulatan sejati, yaitu kedaulatan manusia". ${ }^{10}$ Jadi, keamanan nasional bukan saja harus selaras dengan prinsip-prinsip global, tetapi juga antisipatif terhadap dinamika global. Karena itulah, strategi keamanan nasional harus dibangun berdasarkan prinsip-prinsip di bawah ini:

1. Pemahaman mengenai keamanan komprehensif, didasarkan pada konsep ketahanan nasional (national resilience)

2. Cara pandang keamanan yang seimbang antara state security dan human security

3. Pemahaman bahwa keamanan nasional bukan tanggung jawab pemerintah semata, tetapi seluruh elemen masyarakat

4. Keamanan tidak lagi dipahami sebagai penggunaan kekuatan militer saja

5. Diletakkan dalam hubungan 4 pilar dalam mencapai kepentingan nasional, development, democracy, diplomacy, dan defense. Development menjadi basis demokrasi.

Democracy menjamin diperhatikannya kelompok marjinal dalam pembangunan. Ia memberikan kredibilitas dan internal justification diplomasi di luar negeri. Democracy menjamin kontrol dan supremasi sipil dalam kaitannya dengan defense. Development menjamin peningkatan kemampuan militer dan kesejahteraan prajurit. Defense yang kuat akan memberikan confidence yang cukup dalam praktik diplomacy

\footnotetext{
${ }^{10}$ Ibid. Hal. 7.
} 
6. Faktor pengikat untuk nation building adalah faktor keadilan, bukan hanya sejarah yang diikat dengan aspirasi politik dan bukan kesukuan atau etnisitas. Kesatuan (uniformity) harus ditolak, persatuan (unity) harus diperjuangkan dan dibangun. ${ }^{11}$

Dalam studi keamanan kita juga harus mengenal istilah "Sekuritisasi”. Istilah sekuritisasi pertama diciptakan oleh Ole Waever tahun 1995. Konsep sekuritisasi membahas bagaimana sebuah masalah ditransformasikan oleh aktor-aktor sekuritisasi menjadi sebuah masalah keamanan. Sekuritisasi adalah versi yang ekstrim dari politisasi yang memungkinkan digunakannya cara-cara yang luar biasa atas nama keamanan. ${ }^{12}$ Studi sekuritisasi bertujuan untuk memahami "siapa yang melakukan sekuritisasi, (securitizing actor) terhadap isu atau ancaman apa, dari siapa, (referent object), mengapa, hasilnya apa dan dalam kondisi apa? ${ }^{13}$

Intepretasi sempit dari keamanan berfokus pada negara dan pertahanannya dari serangan militer negara lain. Mazhab Kopenhagen menekankan bahwa keamanan adalah soal bertahan hidup (survival), karena itu masalah keamanan sangat terkait dengan ancaman yang ada (eksis), termasuk masalahmasalah non-militer. Mazhab ini memperluas konsep keamanan menjadi lima kategori, yaitu keamanan militer, lingkungan, ekonomi,

\footnotetext{
${ }^{11}$ Ibid. Hal. 8.

${ }^{12}$ Ibid. Hal. 9.

${ }^{13}$ Ibid. Hal. 9.
}

masyarakat, politik. ${ }^{14}$ Dinamika dari masingmasing kategori ini ditentukan oleh aktor-aktor sekuritisasi, yang didefiniskan sebagai aktoraktor yang melakukan sekuritisasi dengan menyatakan sesuatu dan negara menjadi objek utama yang harus diamankan, yang secara nyata terancam. ${ }^{15}$

Ancaman terhadap negara inilah yang harus diredefinisi, karena di dalam negara terdapat banyak unsur. Umumnya, ancaman terhadap negara an sich dikategorikan sebagai ancaman militer, misalnya dari negara tetangga seperti Malaysia, Australia, atau ancaman militer dari China terkait sengketa Laut China Selatan yang meluas ke Kepulauan Natuna. Akan tetapi, seperti sudah dijelaskan sebelumnya, yang saat ini lebih banyak terjadi adalah ancaman yang sifatnya non-militer, dan tidak hanya menyasar negara, tetapi juga unsur-unsur di dalamnya. Untuk itu, diperlukan sebuah identifikasi yang jelas dan menyeluruh tentang bagaimana perkembangan ancaman tersebut, kapan, bagaimana dan mengapa suatu tingkat ancaman tertentu dapat berkembang menjadi lebih besar.

\section{Sistem Pertahanan Negara}

Di bagian ini penulis akan menyinggung sedikit tentang hubungan ancaman non-militer dan keamanan nasional dengan sistem pertahanan negara. Pertahanan negara juga merupakan salah satu elemen pokok suatu negara karena menyangkut kepentingan untuk melindungi warga negara, wilayah dan sistem politiknya dari ancaman

\footnotetext{
${ }^{14}$ Ibid. Hal. 10.

${ }^{15}$ Ibid. Hal. 10.
} 
negara lain. ${ }^{16}$ Hal ini sejalan dengan pendapat KJ Holsti, di mana pertahanan adalah kepentingan nasional yang dinilai sebagai core value atau sesuatu yang dianggap paling vital bagi negara dan menyangkut eksistensi suatu negara. ${ }^{17}$ Penyelenggaraan pertahanan bukan merupakan suatu hal yang mudah, melainkan suatu hal yang sangat kompleks. Dalam pelaksanaannya, pertahanan nasional melibatkan seluruh warga negara, wilayah, ketersediaan ilmu pengetahuan dan teknologi, pemetaan geopolitik nasional, sumber daya alam, sumber daya manusia dan industri pertahanan nasional. Karena itulah, sistem pertahanan negara dapat membantu menganalisa potensi ancaman non-militer terhadap keamanan nasional di Papua.

Sebelumnya akan dijelaskan, apakah yang dimaksud dengan sistem dan apa hubungannya dengan negara dan ancaman? Sistem adalah kumpulan dari komponenkomponen yang berinteraksi satu dengan yang lainnya demi tujuan dan maksud yang sama. ${ }^{18}$ Teori analisa sistem dari ilmuwan politik Amerika Serikat David Easton menunjukkan pola serupa. Ada proses input, proses, dan output. Dari sudut pandang politik, proses ini dimulai dari penangkapan aspirasi masyarakat (input) yang diolah dan dikonversikan dalam lembaga konversi yang disebut eksekutif, legislatif dan yudikatif, sehingga disebut

\footnotetext{
${ }^{16}$ KJ. Holsti. 1981. International Politics: A Framework of Analysis. New Delhi: Prentice Hall. Hal. 200.

${ }^{17}$ Ibid. Hal. 200.

${ }^{18}$ Roy C. Macridis dan Bernard E. Brown. 1996. Perbandingan Politik. Jakarta: PT. Erlangga. Hal. 36
}

proses. Hasilnya berupa kebijakan yang dibuat berdasarkan aspirasi masyarakat. ${ }^{19}$

Menurut Barry Buzan, negara diidentikkan dengan istilah "pemerintah pusat". ${ }^{20}$ Sedangkan menurut Joel Migdal, negara adalah sebuah organisasi yang tersusun dari beberapa agen-agen, dipimpin dan dikoordinasikan oleh kepemimpinan negara (otoritas eksekutif), yang memiliki kemampuan dan otoritas untuk membuat dan mengimplementasikan aturan yang mengikat untuk semua orang, sejalan juga dengan aturan yang mengikat untuk organisasi-organisasi sosial lainnya, di dalam sebuah wilayah tertentu, dan dapat menggunakan kekerasan untuk memastikan terselenggaranya aturan tersebut. $^{21}$ Dalam kajian hubungan antar bangsa, negara dianalogikan sebagai sebuah organisme yang dapat tumbuh dan berkembang atau justru malah mati. Untuk dapat tetap hidup maka negara harus bisa bertahan dalam mengatasi setiap kesulitan seperti ancaman terhadap eksistensinya, hambatan dalam pemenuhan kebutuhan, tantangan dalam penyelesaian masalah dan gangguan yang datang dari berbagai sektor

Kembali ke teori Easton, sistem tingkah laku politik merupakan suatu unit tersendiri dan akan terus bekerja karena secara konstan mendapat banyak input (tuntutan dan dukungan). Sistem sebagai sebuah konsep

\footnotetext{
${ }^{19}$ Ibid. Hal. 37.

${ }^{20}$ Barry Buzan. 1991. People States and Fear. An Agenda for International Security Studies in the Post Cold War Era. Hertfordshire: Harvester Wheatsheaf. Hal. 59.

${ }^{21}$ Joel S. Migdal. 1988. Strong Societies and Week States: State-society Relations and State Capabilities in the Third World. New Jersey: Princeton University Press. Hal. 19.
} 
ekologis menunjukkan adanya suatu organisasi yang berinteraksi dengan suatu lingkungan, yang dipengaruhinya maupun mempengaruhinya. ${ }^{22}$ Faktor lingkungan sangat determinan dalam proses politik, serta output yang dihasilkannya. ${ }^{23}$

Menurut Undang-Undang No. 3 tahun 2002 tentang Pertahanan Negara, sistem pertahanan negara adalah sistem pertahanan yang bersifat semesta yang melibatkan seluruh warga negara, wilayah dan sumber daya nasional lainnya, serta dipersiapkan secara dini oleh pemerintah dan diselenggarakan secara total, terpadu, terarah dan berlanjut untuk menegakkan kedaulatan negara, keutuhan wilayah dan keselamatan segenap bangsa dari segala ancaman. Keterlibatan warga negara, wilayah dan sumber daya nasional lainnya, menurut model sistem pertahanan negara yang dibuat oleh mantan Rektor Universitas Pertahanan Indonesia Syarifudin Tippe, adalah input dalam keseluruhan proses pertahanan negara.

Penulis berpandangan bahwa, input tersebut belum diolah dan masih bersifat baku dan mentah. Konsepsi warga negara, wilayah dan sumber daya nasional lainnya belum diproses menjadi output yang keluarannya adalah kedaulatan, keutuhan dan keselamatan bangsa dan NKRI. Karena itulah, input terdiri dari tuntutan rasa aman, tuntutan keselamatan bangsa, tuntutan integritas, kedaulatan,

22 Mochtar Mas'hoed dan Colin MacAndrews. 2001. Perbandingan Sistem Politik. Yogyakarta: Gadjah Mada University Press. Hal. 24-25.

${ }^{23}$ Lebih lengkapnya bisa lihat, Ikuo Kabashima dan Lynn T. White III (ed). 1986. Political System and Change. New Jersey: Princeton University Press. Hal. 23-40. keutuhan NKRI dan ancaman pertahanan negara. Dalam konteks Papua, mereka menuntut rasa aman. Dan tuntutan mereka, secara tidak langsung, dapat mengancam pertahanan negara karena banyaknya tindakantindakan melawan hukum, seperti tindakan separatisme yang digaungkan oleh Organisasi Papua Merdeka (OPM).

Sistem pertahanan negara membutuhkan sumber daya nasional yang mumpuni dan paham spektrum ancaman di era modern ini. Untuk itu, penguatan sistem pertahanan negara dapat membantu menetralisir ancaman militer, dan tentunya ancaman non-militer, terkait keamanan nasional di Papua. Sederhananya, jika proses input dari masyarakat Papua direspon dengan positif oleh pemerintah pusat, maka output yang menjadi keluarannya pun akan menjadi positif. Papua tidak akan meminta kemerdekaan karena kepentingannya terakomodasi. Otomatis, ancaman terhadap keamanan nasional pun berkurang.

Penyelenggaraan sistem pertahanan negara tidak hanya dimaksudkan untuk menghadapi ancaman militer, tetapi juga ancaman non-militer yang berasal dari dalam. Demi menjaga keutuhan NKRI, maka pendekatan-pendekatan yang bersifat kesejahteraan layak dikedepankan dalam diskursus ini. Soal-soal kesetaraan, pemenuhan hak asasi manusia, mutual agreement dan dialog menjadi garda terdepan yang harus dilakukan. Kesadaran akan potensi integratif tersebut semestinya menjadi kewajiban pemerintah memupuk secara intens semangat integrasi di atas logika nasionalisme sipil yang 
mengandaikan demokrasi, kesetaraan, keadilan sosial dan kesejahteraan bersama, pluralisme dan penghargaan terhadap HAM.

\section{Ancaman terhadap Keamanan Nasional di} Papua

Pasca runtuhnya Uni Soviet dan masuknya dunia ke era teknologi informasi, pergeseran paradigma keamanan dari state centered menjadi people centered (human security) membuat community participation menjadi tidak terpisahkan dari konsep keamanan nasional, maupun perumusan aturan yang terkait. ${ }^{24}$ Terlebih lagi ketika arus globalisasi berhasil mengangkat nilai-nilai demokrasi dan penghormatan hak asasi manusia ke segala pelosok dunia, muncul kesadaran bahwa masyarakat atau warga negara bukan semata-mata hanya menjadi objek, tetapi juga subjek tatanan kehidupan nasional. Keamanan adalah barang publik (milik masyarakat) sehingga harus dapat dinikmati oleh seluruh masyarakat. ${ }^{25}$

Menurut penulis, situasi di Papua tidak dapat dikategorikan sebagai konflik bersenjata (armed conflict). Papua lebih dikategorikan sebagai kekacauan dan ketegangan, atau gangguan dalam negeri (internal disturbances and tension). Sejauh pengetahuan penulis, dengan menggunakan pengertian atau batasan armed conflict sebagaimana dirumuskan dalam kasus Dusko Tadic di ICTY (International

\footnotetext{
${ }^{24}$ Lebih jelasnya lihat di Bambang Heru Sukmadi. 2010. Keamanan Nasional: Sebuah Konsep dan Sistem Keamanan bagi Bangsa Indonesia. Jakarta: Sekretariat Jenderal Dewan Pertahanan Nasional. Hal. 28.

${ }^{25}$ Ibid. Hal. 28.
}

Criminal Tribunal for the former Yugoslavia), maka situasi di Papua tidak termasuk armed conflict. Kalau kita bicara OPM, penulis rasa mereka baru bisa dikatakan sebagai kelompok bersenjata yang terorganisir jika kelompok tersebut telah mempunyai susunan organisasi yang menunjukkan siapa yang merupakan pimpinan tertinggi sampai dengan terendah, serta mempunyai aturan disiplin yang mengikat bagi anggotanya. Hal ini karena sampai hari ini tidak ada korelasi yang kuat antara pihak-pihak yang ingin merdeka di Papua dengan OPM secara organisasi. Mereka berjuang terpisahpisah, dengan tidak selalu membawa bendera OPM. Kondisi yang sangat berbeda dengan Aceh, di mana perjuangannya selalu berada di bawah komando GAM, dengan struktur organisasi yang jelas.

Ukuran terorganisirnya suatu organisasi militer dilihat dari rantai komando dan aturan disiplin yang berlaku secara internal di dalam organisasi militer yang bersangkutan. Meskipun pengorganisasian dan ketentuan disiplin internal tersebut tidak harus ketat seperti suatu organisasi militer dari angkatan bersenjata reguler, namun setidaknya menunjukkan adanya suatu rantai komando di dalam organisasi kelompok bersenjata tersebut, yang memungkinkan pimpinan tertinggi melakukan komando dan kontrol atau merencanakan suatu operasi militer yang terencana. Apabila suatu kelompok bersenjata melakukan operasi atau aksi-aksinya tanpa didasarkan kepada suatu rencana yang dikoordinasikan oleh pimpinan tinggi, maka tindakan tersebut tidak dapat dikatakan sebagai suatu operasi militer, tetapi merupakan suatu 
tindakan kekerasan menggunakan senjata yang

dilakukan oleh kelompok bersenjata.

Di era perang dingin (cold war) dan sesudahnya, pendekatan keamanan dari sisi ilmu militer (military science) dirasakan kurang dapat menyelesaikan segenap potensi ancaman yang timbul. Bagi setiap negara khususnya Indonesia, hadirnya aktor non-state dalam bentuk kelompok (network) nonregular militaries (seperti OPM contohnya) menjadikan spektrum ancaman semakin kompleks. Keamanan nasional bukan lagi sekedar kondisi di mana ancaman dapat diatasi, tetapi juga harus mampu bertahan dalam skala nasional, situasi regional, bahkan global. Maka, lahirlah istilah spesifik seperti pengaturan keamanan/ketahanan (defence management), ketahanan ekonomi (defence economics), ketahanan finansial (defence finance), ketahanan energi (energy security), ketahanan informasi (cyber security) dan ketahanan terhadap bencana alam (disaster management), serta conflict resolution.

Ahli-ahli studi perdamaian mulai menjawab permasalahan-permasalahan, seperti kejahatan genosida (pasca PD II), perlombaan senjata antara blok barat dan timur, perang sipil, konflik ras, agama, sosial, sampai isu terorisme pada era itu. Intra-state conflicts (konflik internal dalam sebuah negara) macam ini membuat ancaman nyata terhadap sistem pertahanan sebuah negara, apalagi ketika interstate conflict (konflik antarnegara) semakin jarang terjadi pasca PD II. Dari tahun 1990 sampai 1994 terjadi sekitar 49 konflik bersenjata di dunia dan 25 diantaranya menyebabkan korban tewas dan sangat sedikit diantaranya yang merupakan konflik antarnegara. ${ }^{26}$ Konflik-konflik lokal, komunal, horisontal, dll terbukti menjadi ancaman nonmiliter bagi keamanan nasional yang harus segera ditangani.

Kembali ke masalah Papua, keinginan masyarakat Papua untuk merdeka lebih disebabkan karena mereka tidak mengalami kesetaraan dalam hal kesejahteraan dengan propinsi-propinsi lain di Indonesia. Fakta berbicara bahwa pemerintah pusat mengalokasikan triliunan rupiah untuk dana alokasi Papua. Ini pun belum termasuk dana tambahan yang jumlahnya ditetapkan DPR atas usulan dari gubernur. Ditambah dengan dana Otonomi Khusus (Otsus) yang setiap lima tahun mencapai kurang lebih 30 triliun, harusnya pembangunan Papua sudah sangat terjamin. Akan tetapi, dana sebesar itu tidak sampai kepada yang membutuhkan. Terlalu banyak permasalahan dari sisi birokrasi di Papua yang menyebabkan alokasi sumber daya menjadi tidak setara. Barry Buzan secara sederhana mengatakan, bahwa untuk mengerti keamanan nasional selalu dibutuhkan interdependence antar semua stake holders agar kesemuanya merasa aman (secure). ${ }^{27}$ Interdependence dibutuhkan agar alokasi sumber daya menjadi setara. Sayangnya, hal itu tidak terlihat di bumi Papua.

Penulis berpendapat bahwa kondisi seperti inilah yang akan melahirkan kondisi

\footnotetext{
${ }^{26}$ Malvern Lumsden dan Rebecca Wolfe. 1996. Evolution of a Problem Solving Workshop: An Introduction to Social-Psychological Approaches to Conflict Resolution, Journal of Peace Psychology. Hal. 1

${ }^{27}$ Buzan. Op cit. Hal. 2.
} 
instabilitas di Papua. Jika tidak ada penanganan yang serius, kondisi ini akan berkembang menjadi kondisi permanen, yang tentunya akan menjadi ancaman besar terhadap keamanan nasional. Contohnya, watak kekerasan yang melekat dan berkembang, seperti api dalam sekam yang berdimensi suku, agama, ras dan antargolongan, pada dasarnya timbul akibat watak kekerasan yang sudah melekat. Kondisi ini sudah barang tentu menjadi ancaman terhadap socio-political stability, yang diwujudkan pada adanya keinginan untuk merdeka atau secessionist movement.

Watak kekerasan itu pula yang mendorong tindakan kejahatan termasuk perusakan lingkungan dan bencana buatan manusia. Ancaman terhadap ecological balance, seperti ekspolitasi sumber daya alam, menjadi kepedulian kita bersama untuk diatasi. Bersamaan dengan itu banyaknya sengketa antarwilayah di Papua, yang melibatkan sukusuku lokal juga mengancam territorial integrity Papua. Belum lagi ketimpangan ekonomi antara orang Papua asli dengan pendatang, yang sering mengakibatkan konflik antar mereka. Tentunya kondisi ini sangat berpengaruh terhadap economic sustainability mereka.

Exploitation of natural resources, economic disparity, dan homogenization of cultural identity and local government menjadi faktor-faktor ancaman non-militer yang sudah dan akan terus terjadi di Papua jika kita tidak berbuat sesuatu terhadapnya. Tiga faktor di atas yang bisa kita kategorisasikan masuk dalam proses sekuritisasi ini mengancam stabilitas keamanan di Papua dalam jangka panjang, karena secara tidak langsung "menyerang" urat nadi kehidupan masyarakat di Papua. Bayangkan tanpa sumber daya alam yang mencukupi, maka terjadilah ketimpangan ekonomi yang meluas, yang sulit diatasi tanpa masyarakat yang masih mempertahankan identitas kulturalnya. Identitas kultural orang Papua perlahan tergerus oleh individualisme personal yang bersaing memperebutkan sumber daya.

Akhirnya, penulis berkesimpulan bahwa faktor-faktor tersebut berproses secara meluas, serta menghasilkan efek domino sehingga dapat melemahkan kualitas bangsa Indonesia secara keseluruhan. Apalagi konflik berdimensi vertikal antara pemerintah pusat dan daerah, seperti penyeragaman identitas budaya dan pemerintahan lokal, serta pendekatan keamanan represif yang sering diterapkan pemerintah pusat, merupakan ancaman besar terhadap cultural cohesiveness Papua, dan tentunya external peace and harmony Indonesia secara umum. Jadi sekali lagi, ancaman terhadap keamanan nasional di Papua sebenarnya bukanlah konflik bersenjata (militer), tetapi memang ancaman non-militer.

Bicara keinginan Papua untuk merdeka, gagasan John Herz tentang "security dilemma" juga bisa kita kaji dalam konteks disintegrasi seperti ini. Herz mengatakan, aktor internasional dalam upaya memenuhi kebutuhannya (termasuk keamanannya) terkadang bersingguhan satu sama lain. Hal ini membuat semuanya merasa terancam dan bersikap defensif (tidak terbuka) antar satu 
sama lain. ${ }^{28}$ Papua merasa bahwa mereka harus melakukan all means untuk mendapatkan kesejahteraan, akan tetapi langkah-langkah itu bersingguhan dengan aturan yang berlaku di Republik Indonesia. Persingguhanpersingguhan macam ini memang umumnya terjadi dalam konteks Internasional (antarnegara), akan tetapi berkembangnya ancaman-ancaman internal membuat konsep "security dilemma" menjadi relevan dikaitkan dengan masalah Papua.

Dalam konteks internasional, Confidence Building Measures (CBM) menjadi salah satu upaya positif mengatasi "security dilemma". Mutual agreement dan defense cooperation menjadi dua kata kunci yang bisa kita kembangkan di sini. Dalam hal defense cooperation antara Indonesia dengan negara lain (lingkungan), perlu juga kita amati persoalan Confidence Building Measures (CBM). Menurut Dipankar Banerjee, keberadaan CBM dipertanyakan di dunia internasional. Hal ini karena implementasinya sangat bergantung pada realitas politik dan tingkat hubungan antarnegara. Mereka akan bekerja sama apabila ada keinginan dan kepentingan untuk itu. CBM bisa dipahami juga sebagai langkah-langkah menghindari konflik (conflict avoidance measures), walaupun masih sangat tergantung political will dari negara-negara yang terkait. Akan tetapi, jika katakanlah ada saja sedikit keinginan untuk menghindari perang, maka keberadaan CBM dalam konteks

\footnotetext{
${ }^{28}$ John H. Herz. 1959. International Politics in the Atomic Age. New York: Columbia University Press. Hal. 231.
}

interrelationship dan defense cooperation patutlah didukung. $^{29}$

Menurut Pervaiz Iqbal Cheema, CBM dapat meningkatkan kesepakatan umum antarnegara yang kemungkinan berkembang menjadi perjanjian formal antar negara-negara tersebut. Bahkan, CBM dapat diimplementasikan dalam beberapa kategori, seperti konsultasi, batas-batas, transparansi, keamanan dan tindakan-tindakan preventif, dll. ${ }^{30}$ Dengan ini, negara menyadari potensi mereka, serta pentingnya mengadakan kerjasama dengan negara-negara lain. Bagi Indonesia, kerjasama yang kuat dengan negara lain akan memperkokoh kedaulatan dan keutuhan NKRI. ${ }^{31}$

Bicara kedaulatan dan keutuhan NKRI, penulis merasa perlu menerapkan konsep yang mirip dengan CBM dalam konteks nasional. Konsep integrasi dengan perlakuan yang adil bagi masyarakat Papua perlu dikedepankan. Ketika ada mutual agreement dalam konteks CBM, perlu juga dibuat semacam kesepakatan dalam konteks nasional agar semangat integrasilah yang muncul di Papua, dibandingkan dengan disintegrasi. Integrasi akan memunculkan potensi-potensi lokal Papua sehingga koheren dengan semangat kebangsaan.

Kesadaran akan potensi integratif tersebut semestinya menjadi kewajiban pemerintah memupuk secara intens semangat integrasi di atas logika nasionalisme sipil

29 Dipankar Banerjee (ed). 1999. Confidence Building Measures in South Asia. Colombo: Regional Centre for Strategic Studies. Hal. 1.

${ }^{30}$ Ibid. Hal. 31.

${ }^{31}$ Ibid. Hal. 31. 
(memakai istilah Jack Snyder) yang mengandaikan demokrasi, kesetaraan, keadilan sosial dan kesejahteraan bersama, pluralisme dan penghargaan terhadap HAM. Dalam konsep sistem pertahanan semesta, sistem pertahanan negara kita adalah dengan melibatkan warga negara dalam upaya-upaya pertahanan negara. Dalam pemahaman penulis, dialog adalah elemen penting jika kita ingin mencegah ancaman disintegrasi Papua. Pendekatan-pendekatan yang sifatnya kesejahteraan layak dikedepankan dalam diskursus ini. Soal-soal kesetaraan, pemenuhan hak asasi manusia, mutual agreement dan dialog menjadi garda terdepan dalam upayaupaya menyelesaikan masalah-masalah di Papua.

Oleh karena itu, setiap negara cenderung memperkuat kemampuan respon non-militer masing-masing tanpa meninggalkan kemungkinan dilakukannya respon militer. Untuk menghadapi ancaman yang tingkat kompleksitasnya semakin tinggi, dengan sendirinya negara dituntut untuk mampu melakukan respon yang komprehensif dan terpadu antara respon militer dan nonmiliter secara efektif, baik dalam tataran global, regional dan tentunya domestik. ${ }^{32}$

Kalau kebijakan Otonomi Khusus (otsus) dianggap "berlebihan" (eksesif), hal itu bisa didialogkan dengan jujur dan damai, bukan dengan "mengangkangi" aturan tersebut tanpa alasan yang jelas. Kalau Undang-Undang No 21 tahun 2001 tentang Otsus Papua dianggap menafikan NKRI dan bakal

\footnotetext{
${ }^{32}$ Sukmadi. Op cit. Hal. 32.
}

melahirkan "negara dalam negara", hal itu juga tak harus dengan menunjukkan sikap kecurigaan yang berlebihan. Pembangunan kebijakan yang berskala nasional, seperti UU Otsus tersebut, harus memiliki paradigma pendekatan keamanan yang berorientasi pada kesejahteraan (people centered). Dalam perspektif politik multikultural, kenyataan itu tak menjadi masalah. Wilayah yang terbentang dari Sabang hingga Merauke ini adalah sebuah bangsa besar yang terdiri dari "bangsa-bangsa" yang lebih kecil. "Bangsa-bangsa" di sini tentu merujuk kepada pengertian kesatuan identitas, ras, bahasa ibu dan sebagainya. Dalam konteks negara multi-bangsa, tak ada alasan logis buat Papua untuk memisahkan diri dari NKRI. Ancaman terhadap keamanan nasional di Papua seharusnya dapat diatasi dengan meningkatkan partisipasi masyarakat Papua itu sendiri.

Undang-undang yang dibuat pusat bagi Papua tidak boleh lagi dirumuskan sekedar oleh perwakilan pemerintah pusat dengan elitelit Papua semata. Seperti analogi kredo pertahanan negara (sesuai UU Pertahanan Negara), yang melibatkan partisipasi warga negara, maka setiap manusia Papua harus turut serta melibatkan dirinya sendiri dalam pembahasannya. Karena pertahanan negara merupakan salah satu elemen pokok suatu negara, dan menyangkut kepentingan untuk melindungi warga negara, wilayah dan sistem politiknya, maka keterlibatan segenap unsur masyarakat sangat diharapkan.

Paradigma pembuatan undang-undang kita harus bergeser dari pasif, menjadi aktif. Selama ini undang-undang (aturan) dibuat 
terlebih dulu oleh elit, lalu kemudian setelah jadi disosialisasikan kepada masyarakat (pasif). Penulis berpendapat, proses sosialisasi itu harus dilakukan di awal agar masyarakat paham dan mengerti benar roh dan semangat dari undang-undang yang akan diusulkan itu. Termasuk juga mereka merasa aman (secure) karena terlibat dalam prosesnya. Ketika masyarakat Papua secara kultural dan sosiologis dapat menerimanya, maka tingkat kepatuhannya pun akan semakin tinggi. Seperti teori Easton di atas, input harus diawali dari masyarakat, bukan sebaliknya.

\section{Kesimpulan}

Ancaman non-militer adalah ancaman yang menggunakan faktor-faktor non-militer, yang dinilai mempunyai kemampuan yang membahayakan kedaulatan negara, keutuhan wilayah negara dan keselamatan segenap bangsa. Ancaman non-militer dapat berdimensi ideologi, politik, ekonomi, sosial budaya, teknologi dan informasi serta keselamatan umum. Ancaman non-militer sangat berdimensi sosial budaya karena sifatnya yang internal, alias muncul dari dalam negara. Ancaman non-militer didorong oleh isu-isu kemiskinan, kebodohan, keterbelakangan, dan ketidakadilan. Isu tersebut menjadi titik pangkal timbulnya permasalahan, seperti separatisme, terorisme, kekerasan dan bencana akibat perbuatan manusia.

Penyelenggaraan sistem pertahanan negara tidak hanya dimaksudkan untuk menghadapi ancaman militer, tetapi juga ancaman non-militer yang berasal dari dalam. Demi menjaga keutuhan NKRI, maka pendekatan-pendekatan yang sifatnya kesejahteraan layak dikedepankan dalam diskursus ini. Soal-soal kesetaraan, pemenuhan hak asasi manusia, mutual agreement dan dialog menjadi garda terdepan yang harus dilakukan. Dialog tidak akan mengambil nyawa siapapun, malah akan bermuara pada kesejahteraan. Dialog hanya menakutkan bagi mereka yang selama ini mengambil keuntungan dari kekacauan, kekerasan, ketidakjelasan dan status quo. Mereka yang anti dialog adalah orang-orang yang menjadikan kekerasan dan ketidakadilan sebagai sumber mata pencaharian dan kekuasaan yang biasanya mengatasnamakan bangsa dan negara, atau mengatasnamakan rakyat Papua, bahkan mengatasnamakan suku atau agama.

Pembangunan kebijakan yang berskala nasional, seperti UU Otsus, harus memiliki paradigma pendekatan keamanan yang berorientasi pada kesejahteraan (people centered). Dalam perspektif politik multikultural, kenyataan itu tak masalah. Wilayah yang terbentang dari Sabang hingga Merauke ini adalah sebuah bangsa besar yang terdiri dari "bangsa-bangsa" yang lebih kecil. "Bangsa-bangsa" di sini tentu merujuk kepada pengertian kesatuan identitas, ras, bahasa ibu dan sebagainya. Dalam konteks negara multibangsa, tak ada alasan logis buat Papua untuk memisahkan diri dari NKRI. Ancaman terhadap keamanan nasional di Papua seharusnya dapat diatasi dengan meningkatkan partisipasi masyarakat Papua itu sendiri.

Penulis merasa usulan rekomendasi kebijakan yang pas untuk Papua harus 
diletakkan dalam kerangka kedaulatan dan keutuhan NKRI. Konsep integrasi dengan perlakuan yang adil bagi masyarakat Papua perlu dikedepankan. Ketika ada mutual agreement dalam konteks undang-undang yang dibuat pemerintah pusat bagi Papua, perlu juga dibuat semacam kesepakatan dalam konteks lokal agar semangat integrasilah yang muncul di Papua, daripada disintegrasi. Integrasi akan memunculkan potensi-potensi lokal Papua sehingga koheren dengan semangat

\section{DAFTAR PUSTAKA}

Aditjondro, George Junus. 2000. Cahaya Bintang Kejora: Papua Barat dalam Kajian Sejarah, Budaya, Ekonomi, dan Hak Asasi Manusia. Jakarta: Elsam.

Banerjee, Dipankar (ed). 1999. Confidence Building Measures in South Asia. Colombo: Regional Centre for Strategic Studies.

Buzan, Barry. 1991. People States and Fear. An Agenda for International Security Studies in the Post Cold War Era. Hertfordshire: Harvester Wheatsheaf.

Herz, John H. 1959. International Politics in the Atomic Age. New York: Columbia University Press.

Holsti, KJ. 1981. International Politics: A Framework of Analysis. New Delhi: Prentice Hall.

Indrawan, Jerry. 2015. Studi Strategis dan Keamanan. Jakarta: Nadi Pustaka.

Kabashima, Ikuo dan Lynn T. White III (ed). 1986. Political System and Change. New Jersey: Princeton University Press. kebangsaan. Hasilnya, undang-undang tadi bukan sekedar macan kertas yang mengikat secara hukum, tapi juga dipatuhi secara sosial maupun budaya. Sederhananya, jika proses input dari masyarakat Papua direspon dengan positif oleh pemerintah pusat, maka output yang menjadi keluarannya pun akan menjadi positif. Papua tidak akan meminta kemerdekaan karena kepentingannya terakomodasi. Otomatis, ancaman terhadap keamanan nasional pun berkurang.

Lumsden, Malvern dan Rebecca Wolfe. 1996. Evolution of a Problem Solving Workshop: An Introduction to Social-Psychological Approaches to Conflict Resolution, Journal of Peace Psychology.

Macridis, Roy C. dan Bernard E. Brown. 1996. Perbandingan Politik. Jakarta: PT. Erlangga.

Mas'oed, Mochtar dan Colin MacAndrews. 2001. Perbandingan Sistem Politik. Yogyakarta: Gadjah Mada University Press.

Migdal, Joel S. 1988. Strong Societies and Week States: State-society Relations and State Capabilities in the Third World. New Jersey: Princeton University Press.

Pigay, BIK. dan Decki Natalis. 2000. Evolusi Nasionalisme dan Sejarah Konflik di Papua. Jakarta: Pustaka Sinar Harapan.

Sukmadi, Bambang Heru. 2010. Keamanan Nasional: Sebuah Konsep dan Sistem Keamanan bagi Bangsa Indonesia. Jakarta: Sekretariat Jenderal Dewan Pertahanan Nasional. 
